\title{
The Discursive Construction of the Public and the Private Spheres in Media Debates: The Case of Television Talk Shows
}

\author{
Marcel Burger \\ University of Lausanne \\ marcel.burger@unil.ch
}

\begin{abstract}
Within the framework of an interactionnist perspective on discourse analysis, this paper deals with the discursive construction of the public and private spheres in media debates. Focusing on the French media, one observes a current trend to mix up the construction of the public and the private spheres in the practice of media information and more generally a shift from civic information to pure spectacle. This state of affairs is particularly manifest in debates. We first discuss this issue and then define the discursive properties of three types of debates. One of these: the statement's talk show debate manifests best the blurring of boundaries between public and private domains. Finally, we analyze the discursive dimension of an excerpt of a well-known French program ("C'est mon choix": FR3 channel), which is representative of this genre. Our analysis focuses on the discursive performance of the hostess as it is essential to understand what is at stake with media debates.
\end{abstract}

\section{Introduction: theoretical perspective, data and problem}

This article is part of a broader research on the issue of media debates ${ }^{1}$ in the French speaking media (Burger 2002b, 2002c, 2004, 2005, in press, Burger and Filliettaz 2002). One observes in the field of discourse analysis (see Perrin, 2006, Perrin and Ehrensberger, forthcoming, Burger and Martel 2005, Charaudeau 2005) as well as in the field of communication and media studies (see Maigret and Macé 2005, Siracusa 2002, Neveu 2001), a current trend of the French media to mix up the construction of the public and the 
private spheres in the practice of media information. In our own research we observe that this state of affairs is especially manifest in media debates. In this paper, we will first deal with this issue and concentrate on the discursive dimension of public and private sphere in media debates (section 2). Then, we will define the discursive and communicative properties of three major genres of debates. One of these: the statement's talk show debate manifests best the blurring of boundaries between public and private domains and more generally the shift from civic information to pure spectacle in the media (section 3 ). Finally, focusing on statement's talk show debates, we analyze the discursive dimension of an excerpt of a recent well-known French program ("C'est mon choix", broadcast by FR3 channel), which is representative of this genre. Our analysis focuses on the role identities endorsed by the hostess and especially her discursive performance. Indeed, this latter dimension seems essential as it helps to better understand the actual practices of the broadcast media (section 4 ).

We adopt the theoretical framework of social interactionism in the field of discourse analysis (see Perrin 2006, Filliettaz 2002, Burger 2002a, for a global presentation). In a very broad sense, a social interactionist perspective assumes the dialogical nature of human practices as introduced by Bakhtin and Foucault and concentrates on the link between texts and discourse and particular social practices, in our case the practice of the media. Therefore, a social interactionist perspective in the field of discourse analysis focuses on the role of discourse as a leading resource in the negotiation of meaning and the construction of social realities. One can briefly characterize such a perspective in taking into account three important dimensions:

\section{a) The cognitive dimension of communication and discourse}

The historical background of social practices constitutes the first important dimension of communication and discourse. More precisely, one hypothesizes that the social practices, being constantly repeated by the participants, manifest typical properties that lead to constitute social expectations located in the mind of social agents (see for example Harre and Gillett 1994, Shotter 1995). Therefore, these social expectations at the same time frame activities and are constantly revised and updated due to the particular course of activities in day-to-day performed practices. In other words, "expectations" represent a kind of social and ideal "guide" for the interpretation of the activity in which participants engage: they explain part of the performance, including the discourse that is held (see in particular Levinson, 1992; Bronckart, 1997; Filliettaz, 2002).

On the basis of their exposure to a particular event or activity type, one hypothesizes that the participants have access to their "expertise", that is, an organized net of mental representations of the key features of the activity types in which they engage. Thus, one admits that the participants, when communicating, construct and exploit inferential schemata and context models including relevant information about, notably, the aim of the activity, the identities of legitimate participants and the expected communicative resources that are used, including language and discourse. On such an "ideal" basis, communicators 
then inter-act to achieve particular goals by the means of particular strategies (Van Dijk, 1990; Filliettaz, 2002; Burger, 2002a).

\section{b) The interactional dimension of communication and discourse}

In this view, besides the cognitive dimension, communication and discourse also manifest an interactional dimension. Following Goffman (1983), Cicourel (1991), and more recently Shotter (1995) and Scollon (1998), one assumes that activities are jointconstructions. In other words, they are collectively managed, negotiated, and even performed. In this view, communication and discourse are not simply semantically constrained, but also pragmatically negotiated by the participants. Any kind of social practice manifests the tracks of communicative strategies and the confrontation of opinions and points of view. As a matter of fact, in the framework of an interactionist approach to communication and discourse, social realities do not exist objectively independently from the way they are thought and individually experienced and performed in particular activities. More precisely, the interactive "struggle" and negotiation by the communicators play a key role in the construction of a social reality, as we will see in section 4 . As a conclusion, social realities are emerging from communication and discourse.

\section{c) Discourse as a resource for communication}

This leads to the third important dimension of communication and discourse. Language and discourse represent a decisive resource of negotiation used by the participants engaged in an activity. For instance, as shown amongst others by Habermas $(1987$; 1993), metacommunication is only possible through language and discourse. In a social interactionist perspective, one hypothesizes that discourse contributes decisively to the construction of shared social knowledge: as an example, intentions and strategies can come under discussion at any time during an activity, which represent the one and only way to explicit agency, organize and resolve co-operation (Filliettaz, 2002; Perrin, 2006). Even identities are not only brought into communication and activity, but are constantly (re)defined discursively during the communicative event (see Shotter and Gergen, 1989; Zimmerman, 1998; Burger, 2005). In this sense, the linguistic expression and discursive choices is an essential dimension of the framing of an activity and/or communication. In the case we are concerned with, the discursive dimension of debates is quite fundamental as the expression of opinions that characterize the genre would not be possible. More generally one assumes that the practices of the media are almost entirely constituted by and through discourse.

\section{Constructing discursively the public and the private spheres in the media}

Following Livingstone and Lunt (1994) and Bourdieu (1996) in the field of sociology of the media, as well as Van Dijk (1991) and Charaudeau (1997) in the field of discourse analysis 
of the media, one hypothesizes that media debates constitute particular "genres" that manifest the traditional functioning and role of the media. Indeed, media debates are aimed at reporting opinions anchored in public discussion. In this view, media debates contribute to the construction of the link between the public sphere of citizenship and the private sphere of individuals. There are numerous references made to the notions of public and private spheres in the field of media studies (as an example, see Scannell, 1991; Bell and Garrett, 1998; Neveu, 2001; Maigret and Macé 2005; Charaudeau 2005). One observes that these studies mainly refer to the original work of Jürgen Habermas focusing on communication in modern European societies. Considering the structure of societies, Habermas $(1987,1993)$ opposes a private sphere (or private space) that comprises all the activities, including discursive activities, performed in a rather close, private environment by agents considered as individuals. Besides, the social structures are organized and ruled by the activities of, say, "professional" agents whose expertise manifest that they know what a society is or should be made of: the politicians. Habermas's essential claim is the need to consider a third sphere to understand the functioning of societies: the public sphere (or public space), which is mediated by the two former spheres. The public sphere comprises all activities, including discursive activities, performed in a public, rather open environment by agents considered as citizens. Indeed, this sphere is "public" for all citizens are empowered to engage in, and to contribute to organizing it. More generally, all actors in the public sphere are expected to feel concerned by the ongoing of public affairs: health care, education, security etc. Thus, the public sphere is bounded by civic concerns as opposed to the private sphere, which is constituted by strictly individual claims, as well as to the political sphere, where agents are spokespersons of a majority of citizens, at least in democratic societies.

In this view, the media play an essential (and complex) role: they contribute to the construction of the public sphere as they report the ongoing of public affairs and/or request the politicians to communicate what is at stake with the ongoing of public affairs. In other words, the media necessarily resort to the construction of citizenship (see Livingstone and Lunt, 1994; Bourdieu, 1996; Charaudeau, 2005). But at the same time, the media are economically constrained enterprises addressing customers in the private sphere (see Jacobs, 1999; Croteau and Hynes, 2001, Perrin and Ehrensberger, forthcoming). As a matter of fact, the civic concern of the media is then depending on and determined by the commercial concern. Both dimensions of "newsworthiness" constrain the organization of media discourses, in which tracks of these constraints are manifested. The complexity of the functioning of the media practices, and therefore the complexity of media discourses, is then increased by the relations between the media and both the private sphere of economy (i.e. the practices of advertisement) and the political sphere (i.e. the practices of the government). To work properly, each sphere needs the others, and this state of affairs leads to blur the boundaries of the public, private and political concerns.

The media address their audiences through various genres of communication, but one can nevertheless identify three majors domains in which these genres are anchored: advertisement, leisure and information. The two former call in favor of the discursive and 
visual construction of a playful and fictive social reality, as opposed to the latter, which implies the manifestation of a serious and "real" social reality (see Charaudeau, 1997; Jost, 2001; Maigret and Macé, 2005; Burger, 2005; Perrin, 2006).

I will concentrate on the practice of information in the media, which is itself complex as it is realized by various genres of communication: news, reportage, interview, debate etc. Amongst these genres, I do focus on the latter (i.e. debates) and consider only debates on television. Following Charaudeau and Ghiglione (1997), Neveu (2001) as well as Tolson (ed.) (2001), one can hypothesize that TV debates manifest best how media information at present tends to blur the division between the construction of the public and the private spheres. Indeed, one observes that TV debates constantly mix up markers like "real", "fictional", "serious", "playful" and allow different categories of participants to intervene on the media scene: politicians and experts in certain social domains, but also lay people. As for the audience, it is not anymore addressed only as citizens, but clearly considered also as simple "watchers" of a media spectacle (Scollon, 1998; Burger, 2004), and even as legitimate participants of an entertainment (Myers, 2001; Burger, 2005; Maigret and Macé, 2005).

All media debates seem to manifest this somehow paradoxical functioning of the practice of media information, even a priori serious political debates. At the same time, talk shows debates a priori based on entertainment do very often address social issues relevant for public discussion. As a matter of fact, media debate as a "genre" is constituted by both dimensions: it represents at the same time, in turn (depending on specific moments), a serious public discussion and an entertaining spectacle (see sections 3 and 4 ). Considering the foregoing, it seems nevertheless that nowadays the media focus more and more on economical goals implying that information becomes a good means to do business. In this view, shifting systematically from the public to the private sphere in media debates seems to represent a major resource exploited by all media to attract the audience and create customer's loyalty. More precisely, in media debates, at present, the focus is more and more on private aspects of lay people's everyday life rather than on objective public issues under discussion by politicians and experts in a particular social domain.

As a matter of fact, the public issue and the public's interest seem to be constructed by the media themselves in general and by the participants of debates in particular from a private point of view. Then, lay people telling their life's experience with emotion and affect equals, or is even much more appreciated, than institutional or political experts providing reasonable argumentative discourse (see Shattuc, 1997; Hutchby, 2001; Tolson, 2001; Neveu, 2001; Charaudeau, 2005; Burger and Martel, 2005).

\section{The Complexity of media debates}

In order to describe the link between the discursive construction of the public and the private spheres in TV debates, and in order to observe more globally what is at stake with media debates, one has to consider the main properties of the practice of media information 
in general and the practice of media debates in particular.

A media debate can be considered as a "multiple social practice" (Jacobs, 1999: 22) or as a complex "site of engagement" (Scollon, 1998: 50-55). As a matter of fact, the complexity of debates lies in the fact that it involves at the same time two different communicative frames with distinct participants and distinct goals, as represented in table 1.

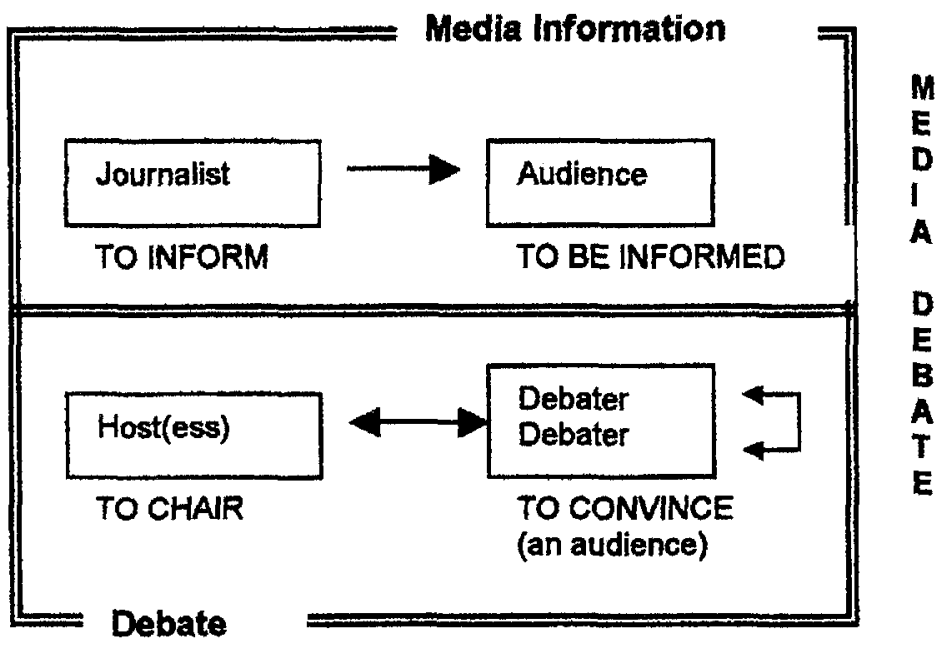

Table 1. The complexity of media debates.

In table 1, we can identify a "talk with" relation (Jucker, 1995: 10) meant by the doublearrow line between a host and at least two debaters. Such a relation constructs and delimits a debate frame in which the activity of some of the participants: the debaters, is aimed at convincing an audience. As for the other participant: the host, he is engaged in the chairing of the interaction (we will detail these activities in section 3.2.). ${ }^{2}$

Concurrently, a media debate obviously engages a one-way relation (meant by the single-arrow line) between a "journalist" and his collective "audience". Such a relation constructs and delimits a media information frame in which the activity of one participant: the journalist, is aimed at informing another participant: the absent audience, about relevant facts and opinions of public interest. According to the communicative complexity of media debates, one has to describe separately each social practice involved in it: the practice of media information first, and then the practice of debates.

\subsection{Media Information as a Social Practice}

It is commonly assumed that media information is a practice under paradoxical constraints. On the one hand, media information has a civic function of informing about the ongoing 
of the public sphere (Nel, 1991; Charaudeau, 1997). Therefore, the media address an audience of citizens, and media information becomes a legitimate means of constructing the public opinion (Livingstone and Lunt, 1994; Bourdieu, 1996). On the other hand, the media are more or less important enterprises doing business in selling information. In this view, the media address at the same time an audience of buyers. Then, media information becomes a legitimate means to win the loyalty of customers (Jacobs, 1999; Croteau and Hynes, 2001; Burger, 2004, 2005) ${ }^{3}$.

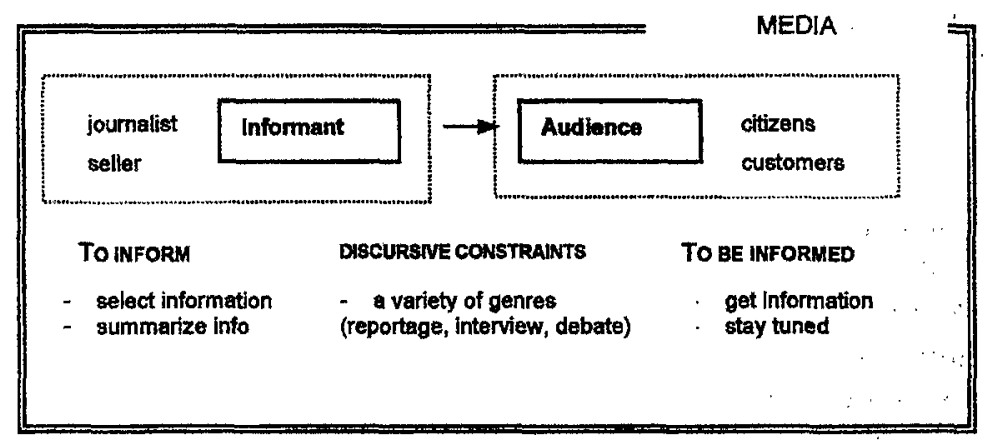

Table 2. Media information as a social practice.

As in table 2, we can define a media information activity in considering the participants, their expected actions and goals, and the discursive genres that they use. I term "informant" the role identity of a journalist engaged in the process of informing his mixed audience of citizens-customers. These identities are brought into being and best sustained by particular types of discursive actions like selecting and summarizing topics in order to attract the audience and make it stay tuned.

As a matter of fact, media information calls for a great variety of discursive genres, from factual genres like a communiqué or a reportage, to genres specialized in the expression of opinions like an interview or a debate. These genres are themselves complex social practices involving specific participants, actions, goals and discursive constraints. In the broadcast we are concerned with, the media information process is linked with a debate process.

\subsection{Debate as a Social Practice}

A debate consists fundamentally in confronting opinions to convince an audience. Therefore, the process of debating implies a multiplicity of voices arguing against each other, and that is why a debate requires a chairperson (or host). The host manages (and avoids deviation from) the agenda and is expected to restore order when the polemic grows. He allocates turns and manages time, re-orientates talk, changes topics and even forces speaker shift. Table 3 represents a debate process taking these elements into account: 


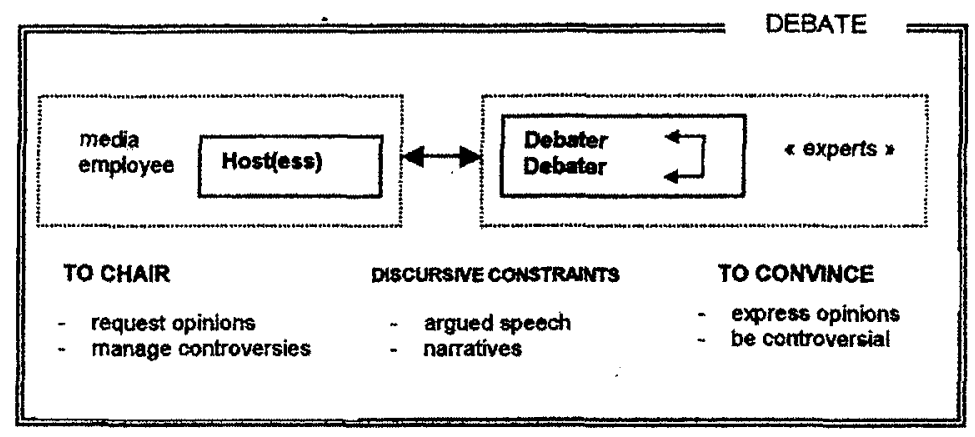

Table 3, debate as a social practice.

The process of debating symbolizes the negotiation of opinions that constitutes the very core of citizenship and democracy (Nel, 1991; Trognon and Larrue, 1994). Therefore, a media debate achieves best the civic function of the media. Located in the frame of media information, the journalist is then a simple 'mediator' reporting opinions to the audience without interfering. But at the same time, the properties of debating also serve the economic function of the media. Indeed, a debate in itself is a verbal confrontation leading often to a spectacular polemic, which constitutes a good means to attract the audience (see Charaudeau and Ghiglione 1997; Hutchby, 1999; 2001). Media information manifests then a commercial concern and displays a different and more active role: that of being the 'creator' of an entertaining show (Burger, 2002; 2005) ${ }^{4}$. In this sense, we will consider how the interventions performed by the host are also used to create confrontation and disruption as these dimensions are potentially entertaining the audience. (section 4).

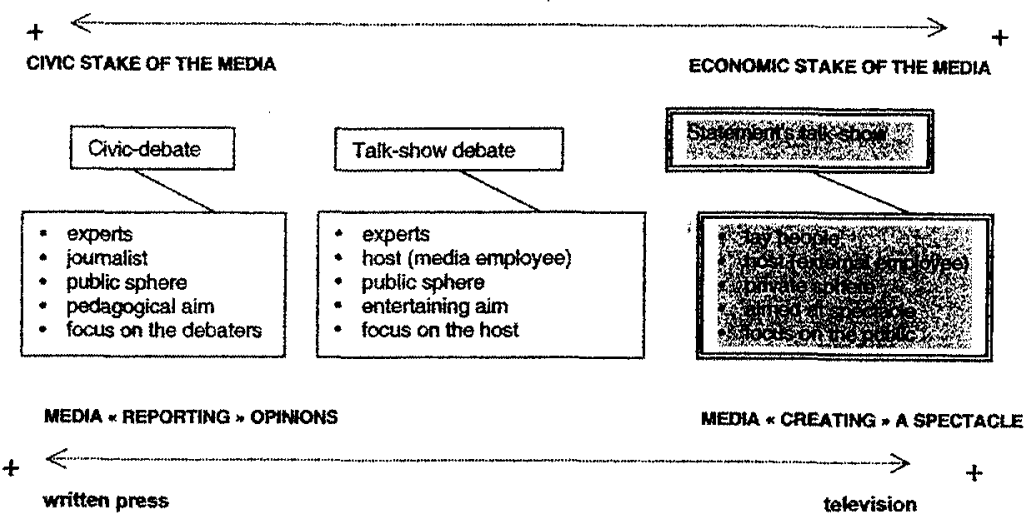

Table 4. the categories of media debates. 


\subsection{The Genres of Media Debates}

In this respect, one can consider media debates depending on whether they reveal a rather serious and pedagogical concern linked with a civic functioning, or manifest an aspect of entertainment linked with an economic functioning.

\subsubsection{The civic debate}

As in table 4, I propose to call "civic-debate" a process engaging a host - who is also a journalist - moving aside from the communicative scene to let space to the debaters who are experts in a specific social domain. In this sense, the debate is focused on the debaters. These participants do not mostly intervene as individuals but as representatives of a group (for example a political party). Therefore, the debaters are confronting opinions that are supposed to be shared and relevant for an audience addressed as citizens who have some interest in the ongoing of the public sphere. Thus, one observes that the debaters try to provide convincing arguments in order to convince the audience. In turn, the audience should compare and then validate one of the discursively expressed opinions to form their own one. Considering the foregoing, a "civic-debate" is explicitly anchored in the public sphere and fundamentally resorts to discourse and argumentation. As a matter of fact, one observes that "rational" discourse anchored in the public sphere of citizenship is clearly dominant in this kind of debates, even if one also observes some moments of pure emotional polemic and "ad personam" confrontation.

\subsubsection{The chat talk-show debate}

I term "chat talk show debate" the second type of media debates. A chat talk show is a process engaging a host - who is most of the time a popular media employee (and therefore not necessarily a journalist) - interfering systematically with the debaters who are experts in a social domain: politics, education, science etc. The popularity of the host puts the debaters in a shade. More precisely, the debaters are at the disposal of the host who acts as a session leader. In this sense, the debate is clearly focused on the host. The issue of the debate is explicitly anchored in the public sphere and therefore presented as relevant for an audience of citizens (and not "private" individuals). Nevertheless, the aim of the "chat talk show debate" genre is obviously to gain customers loyalty by means of entertainment. In this view, the host allows or even provokes systematically the expression of personal opinions, especially from the audience. That is, lay people intervene on the basis of their own opinion, discursively constructed as individuals, yet representative of a group. Their talk is dominated by argumentation, and they struggle to impose their opinion considering a topic, which is obviously presented as a public issue (and not a private affair). 


\subsubsection{The statement's talk-show debate}

Last, I term "statement's talk show debate" a process engaging hosts letting the audience participate in large numbers and provoke the debaters systematically. These are not experts, but lay people telling their life's experience. In this latter case, the real actor of the debate is the audience. In fact, people from the audience are often going on stage, becoming then legitimate "debaters" (even if the media staff is triggering and controlling their performance). As for the host, he is often located in the audience, apparently delegating the floor to the non-expert debaters (of course, the host and the media staff remain the legitimate agents who orchestrate the event). As a matter of fact, this genre of media debates systematically offers very general and "eye-catching" issues to discuss. The topic is then regularly focused on individual opinions and no particular expertise is required to get into the debate. Proposed (or imposed) issues are for example: "I am 30 years old and I have never made love. But I am happy", "I am a fat woman-man ... so what!", or "I do not allow my daughter-son to bring her-his boyfriend-girlfriend at home for the night".

As for the discursive construction of identities, one observes that linguistic markers of the individual (i.e. "I", "me" etc.) are clearly dominant. They are systematically used to represent 'private' agents to the detriment of group members and/or agents considered as citizens. More globally, the requested discourse as well as the provided discourse is anchored in the private sphere. Indeed, they express the singularities of individuals' life experiences, most of the time through narratives.

Considering the foregoing, a "statement's talk show debate" is also expected to be focused on emotions and inter-individual polemic to the detriment of rational argumentation, which constitutes the dominant discursive anchorage of the "civic debate" and the "chat talk-show" genres. This state of affairs implies that no reasoning is provided nor requested. The possibility for an individual to act on stage seems to represent the one and only condition to become a debater shown on television. Then, appearing and performing in the media is the end, and not anymore a means, to put forward a case clearly and eventually resolve a problematic public state of affairs.

Besides, one observes that the audience itself systematically participates in endorsing the identity of a legitimate debater. Thus, one can conclude that there is eventually no need (or not even a possibility) to convince even if the participants struggle to defend and justify their own views. As for the host, he is most of the time an external employee whose skills in leading debates have been proved. That is, the "statement's talk show debates" are often produced by non-media enterprises and sold to particular media.

As a somewhat strange result of "statement's talk show debates", the lack of synthesis and more globally an apparently passive role of the host increase the importance of the audience participation in the construction of public opinion. As it is focused on non-expert opinions, some pretend that the "statement talk show debate" offers a way to regenerate the public sphere (see Livingstone and Lunt, 1994; Bourdieu, 1996 for a discussion). ${ }^{5}$

More precisely, according to Louann Haarman this kind of media debates support a particular emergent media culture as the participants "are often rather crudely displayed 
as emblematic of deviant classes or categories of society". They "belong in large part to the culturally underprivileged" (Haarman 2001: 54). Then, the "statement's talk show debate" becomes the means to teach the audience and lay participants "how to monitor their behavior within (...) prescribed (cultural) norms" (Shattuc 1997: 10). Finally, the "statement's talk show debate" becomes a means to let the underprivileged people "have a majority experience" (Shattuc 1997: 97). In this sense, "private" agents, in telling their particular life's experience, provide "public" information. Thus, "private" (i.e. selfcentered) discourse is relevant in the public sphere though it is not relevant for understanding the ongoing of public affairs. In other words, ordinary emotional talks (and not only rational and argumentative discourses) contribute therefore to manifest the pedagogical aim of a media debate.

Concurrently, the "statement's talk show debate" as a genre leads to a redefinition of the role of the media themselves (and not only of the audience). Thus, a "civic debate" is preferred by the written press that cannot exploit the spectacular dimension of debates (see the left centre of the arrow, in table 4). The written press needs therefore to emphasize the pedagogical dimension of argumentation and functions traditionally, that is, in "reporting" opinions through debates.

Located in the middle of the global opposition of "rational argumentation" versus "emotion and narrative", the "chat talk show debate" is dominant on the radio and television. As a matter of fact, these media can offer two fundamental dimensions of a debate: the spectacle of a living text (radio) and the one of visual emotions (television). One can pretend that "chat talk show debates" constantly hesitate to manifest serious argumentation (which is the main property of a "civic debate"), or to exploit the entertaining dimension of a show (which is the main property of a "statement's talk-show debate").

As for the "statement's talk show debates", they are located on the right of the biaxial layout in table 4 . They support a medium that is explicitly "creating" a spectacle, through debates, to the detriment of the expression and reporting of opinions. Eventually, there are no experts on stage, and there is no audience to convince as everyone represents virtually a legitimate debater (i.e. an agent expressing his life's experience). The host of a "statement's talk show" stands aside the scene, and is acting more as an "exciter" provoking the polemic, than a mediator chairing the debate.

One has to bear in mind that every media debate (i.e. the three categories of "civic debate", "chat talk show debate" and "statement's talk show debate") manifests necessarily both the spectacular and emotional dimension and the rational and argumentative dimension. As a matter of fact, a suite of different sequences structure a media debate (see section 4.3.), emphasizing one of those dimensions. Depending on the role identities of the participants, the debate can then be identified as dominated by argumentation or by emotion and located in one of the three categories of table 4 (considering the double arrow line as a continuum, that is: indicating uncertain contours of each category). In this sense, we hold a view of media debates genres that is not rigid. Indeed, a media debate (whether anchored in the category of "civic", "chat talk show" or "statement's talk show" debate) is always 
a permeable, flexible, dynamic and emergent event.

\section{Case Study: broadcast "C'est mon choix" (FR3/TSR1, 2003)}

\subsection{Profile of the broadcast}

The broadcast we are concerned with clearly manifests the properties of a statement's talkshow debate. It is a very popular French program: 'C'est mon choix' which broadcasts regularly two or three times a day since 1999 on the French public television (channel FR3). As several sessions have been sold abroad, the broadcast also occurs on the French speaking public Swiss television since 2001 (Channel Tsr1). The broadcast is based on the same routine organization, so that the audience is very familiar with it. One can detail several aspects, which work a priori in favor of a high polemic atmosphere to be systematically constructed in order to gain attractiveness. The debate is then a spectacle of individuals confronting without any intention to convince even if they struggle of course to defend their own views. In some respects, the title of the debate: 'C'est mon choix', which means literally "It is my choice", manifests a rather self-centered concern ('my' choice versus 'yours'). It also announces a discourse expected to be anchored in the private sphere emphasizing the power of individuals (my 'choice' versus a 'social constraint').

- First, the topic of each session always touches on a sensitive issue. In our case the title announcing the debate is: "Collecting lovers conquest. What do you think about it?"

- The physical setting is another important element (see Scannell, 1991; Charaudeau and Ghiglione, 1997). In "C'est mon choix", the debaters are on stage facing the audience grouped in the tiered seats together with the hostess. As we will see, the particular position of the host is important as it allows standing aside the scene of the debate as well as letting the audience participate.

- As for the debaters, they are all lay people concerned with the very general issue implying schematic oppositions. In the excerpt below, the hostess - Evelyne Thomas -is requesting the opinion of Damien, a collector of lovers conquests opposed to Fousia a participant coming from the audience.

\subsection{Excerpt of the broadcast}

This is the transcribed text in English from the original in French. Please read Appendix 1 for the transcription conventions. 
STAGE 1

1 HOSTESS

DEB. DAMIEN
Damien Yannick do you like it women acting like you do me yes (..) yes yes me according to me she is hum (.) I mean (.) we we are the same I would like to say
PUBLIC

5 DEB. DAMIEN

DEB. FRÉDÉRIE bouh bouh bouh

yes yes me I adore

it's a game it's a game

STAGE 3

DEB. DAMIEN exactly it's the same for me yes (..) you've got to make a choice (.) either one decides to be the one who is fooled or one decides to be the player (...)

STAGE 2

10 PUBLIC

bouh bouh bouh

STAGE 1

DEB. FOUSIA

Evelyne I would like (.) even so I would like to ask a question to Madam it's hum she that she is collecting but not hunting well the two misters are hunters there is a difference between the struggle for surviving and the collecting because the women in fact she has let's say (..) she is not frustrated but I would say that she has been increased in her awareness in the sense that hum the men they did not respect her (.) she has always been expecting something good and she was not getting anything else than in the evening (..) apparently simply the cooking to do and so on

STAGE 2

20 PUBLIC

DEB. FRÉDÉRIE

DEB. FOUSIA

DEB. FRÉDÉRIE

PUBLIC

25 DEB. FOUSIA

DEB. FRÉdÉRIE

DEB FOUSIA

DEB FRÉDÉRIE

30 DEB. YANNICK

DEB. DAMIEN

DEB. FOUSIA

35 PUBLIC

DEB. FRÉDÉRIE

DEB. FOUSIA ohohohohohoh

this has nothing to do with that

so why are collecting them I suppose that

to get a different one every day

bouh bouh bouh

and love the true love

the what

the true love the true (.) you are (..) the one on which one is basing life the what (.) love how do you write it the word

she she she makes love every day she she loves them totally every day I do not see why staying with the same person it would be love no one cannot one cannot feel totally love in one night it is impossible it already takes a while to know somebody

[thunderous applause for Fousia]

but I don't want to get married with all the guys that went in my bed no no wait I did not say you had to get married but the aim of collecting goes far beyond the idea of respecting oneself and another and respecting 
41 PUBLIC

DEB. YANNICK

46 DEB. FOUSIA

PUBLIC

50 DEB. FRÉDÉRIE

DEB. YANNICK

DEB. FOUSIA the love relation one has built (.) that's all (.) there is no need to collecting we do not live on an island of??

[ applause ]

but she loves all the men and the fact is that we we love all the women (DEB. FRÉDÉRIE : exactly) she she loves all the men she likes to count them she likes to seduce them (DEB. FRÉDÉRIE : that's it) that's what has to be understood.

me I like all the men on the condition that they show consideration to me (DEB YANNICK: ah me I respect one respects you ) but I do not collect them and I don't want them to collect me

[ thunderous applause for Fousia]

why would it be disrespectful

me I spend an evening (.) an evening with a women (.) that (..)during (..) I will devote myself totally from the beginning to the end we will spend a good evening

why from the beginning to the end a good evening it is not it is only a game of collecting (DEB. FRÉDÉRIE : why) why why

STAGE 3

56 DEB. FRÉDÉRIE why if I have done it is it of course that at one point they were showing a lack of respect may be myself I was disrespectful

DEB. YANNICK I strongly recommended her (.) me (.) I strongly recommended her the morality of the three $\mathrm{G}$ (...) good eating (.) good drinking (.) good fu [bip] [public : ah ah ]

\section{NEW DEBATE SEQUENCE}

61 HOSTESS

listen Fousia you will now get some reinforcement since we are introducing our next guests they they absolutely cannot stand men collecting lovers conquests they will tell us if they put up with women collecting men here they are Sylvie and Marilyn

64 PUBLIC

[ applause ]

\subsection{The structural properties of a debate sequence}

This excerpt manifests the typical organization of a debate sequence (see Burger 2004, 2005; Burger and Martel 2005). It begins with a stage of "requesting an opinion" (indicated by the mention: "Stage 1 " in the right margin), then goes on with a stage of "direct confrontation of the opinion" (indicated by the mention: "Stage 2"), and is finally concluded by a stage of "stabilization of the first expressed opinion" (indicated by the mention: "Stage 3").

The first stage engages together the hostess and one of the debaters. The hostess exposes a problematic state of affairs to discuss and asks a debater to express his opinion. This is the case in line 1 . The second stage of direct confrontation engages two debaters 
together. More precisely, the first debater cannot develop his opinion because another debater interrupts him. This stage is therefore a highly polemic and interactive moment, which manifests the entertaining dimension of a show, often to the detriment of the quality of an argument. This is clearly the case from lines 20 to 54 in our excerpt. As for the third stage of a sequence of a debate process, it can be characterized as an attempt to give the floor to the first debater again (who was expected to provide arguments). It involves again a debater and the hostess, once the polemic has been stopped, and that is why I term this stage "stabilizing of an opinion". In our case, this stage does not last long: see for example when Damien in lines 7-9 or Frédérie in line 56 try to talk after a confused polemic.

Globally, all media debates manifest such an organization in several sequences of three stages each. The basic distinction between a "civic-debate", a "chat talk-show debate" and a "statement's talk-show debate" lies in the peculiar role identities performed by the host(ess), that is, respectively, as a moderating or as a triggering element of each stage.

\subsection{The role identities of the hostess}

Following Goffman (1973: 23), one can define the "roles" as the identities displayed during a communicative event by the participants. More precisely, a "role" is an expected and recurrent comportment organizing and explaining the joint-actions of the participants engaged in a particular social practice. In our excerpt, one can observe several "role" identities of the hostess for each stage and relate them to the discursive markers through which these roles are realized ${ }^{6}$.

Table 5. the role identities of the hostess

- Role identities during Stage 1 (stage of requesting an opinion):

a) limiting the floor (instead of issuing the debate);

- in asking a "closed" question;

do you like it women acting like you do (line 1);

b) provoking a confrontation (instead of delaying);

-in promoting an expected answer leading to form an alliance between the debaters:

me yes (..) yes yes me according to me she is hum (.) we we are the same. yes yes me I adore FRÉDÉRIE it's a game it's a game DAMIEN exactly it's the same for me yes (lines 2-9) ;

- in delegating her role to a person (Fousia) from the audience;

in fact she has been not frustrated but say (..) increased in her awareness (lines 11-19);

- Role identities during Stage 2 (stage of direct confrontation):

c) stirring up the confrontation (instead of stopping it);

- in leaving the floor, unseen by the camera (lines 4-60);

d) exploiting the reactions of the audience (to benefit the show);

- in letting the public initiate and punctuate 
bouh bouh bouh / ohohohohohoh (lines 4,10,20,24,35,41,64).

- Role identities during Stage 3 (stage of stabilization of an opinion):

e) interfering in the discourse (instead of letting someone speak);

- in putting a seedy end to the debater's talk (line 60);

f) validating the discourse (instead of simply taking into account the argument);

- in supporting implicitly a participant

listen Fousia you will now get some reinforcements (line 60).

\subsubsection{The role identities during stage 1 of the debate sequence}

Thus, during stage 1 , one can observe that the hostess limits the floor instead of issuing the debate. Indeed, the question she asks calls for a "yes-or-no" answer. Moreover, the expected answer is opposed to the global opinion of the audience. This reveals a means to shorten the first stage, and virtually engage in the second stage, which is the most spectacular. During stage 1, one also observes that the hostess accepts debater Fousia requesting another debater in a highly polemic way (lines 11 to 19). This means that the hostess delegates her identity: she puts herself in a shade letting someone coming from the audience become a debater in the spotlights. Globally, the hostess seeks to shorten the stage 1 , which implies to avoid the possibility to express arguments, and more generally try to shift from simple expression to explicit conflict. Then, what is at stake with the debate is a spectacle with no other aim than that of entertaining a watching audience in their living room, at home. For that reason, the stage 1 of this sequence anchors the debate in the statement's talk show debate genre. More precisely, the conflict between the debaters, which is focused on their private life's experience, involves also the audience in the studio and is certainly aimed at provoking an emotional response of the television viewers.

\subsubsection{The role identities during stage 2 of the debate sequence}

In fact, the audience participation is evident during stage 2 of direct confrontation. Then, the hostess is stirring up the confrontation and exploiting the reactions to benefit the show, instead of stopping the polemic as expected in a civic or in a chat talk-show debate. See for example at lines 4 to 55 how alliances are created engaging Damien, Frédérie and Yannick together against Fousia and the audience managing the conflict alone.

Obviously, the audience in the studio constitutes the real triggering element. It initiates the polemic three times (in lines 4, 10 and 20), and becomes a participant boosting and punctuating the debate (see lines $24,35,41,48$ ). In this sense, the hostess is exploiting the polemic to benefit the show. As a matter of fact, moving aside is implicitly standing for, and supporting the polemic. As for the conflict, it seems evident that all opinions are equally relevant because all the participants are lay people - the debaters as well as the audience.

In this sense, the privacy, and even the intimate dimension of the life's experience that the debaters tell constitutes an element of the construction of a particular sort of public 
sphere: because all the individuals are equal, and because the topic of the sequence leads necessarily to schematic oppositions (i.e. love versus sex), all debaters, as well as the audience in the studio and the television viewers, form a single community, representing the public opinion metaphorically.

\subsubsection{The role identities during stage 3 of the debate sequence}

The focus on a show and not on argumentation seems an essential issue, which explains the peculiar organization of stage 3 . These stages are avoided or shortened because there is eventually no need to convince an audience. The hostess displays then a role-identity consisting in interfering briefly and validating a discourse instead of letting the debaters speak and remaining neutral. See for example how she punctuates without any synthesis the debate sequence in line 61 and initiates a new sequence by calling two other debaters on set.

Displaying such roles confirms the global strategy of developing discursive conflict on the basis of the personal opinions of the debaters. As we have seen, the audience in the studio as well as the television viewers can easily identify themselves with the debaters: all are lay people, all are legitimate participants, all do express personal opinions through minimal argumentation and preferably through narratives, all are supposed to have experienced a similar situation etc.

\section{Concluding Comments}

As a conclusion, one observes that a debate process constitutes a kind of developer of the current double functioning of the media: achieving a civic aim by means of a didactic dimension and achieving an economic aim by means of an entertaining dimension. In the broadcast we are concerned with, the civic dimension is clearly put in a shade by the constantly emerging entertaining dimension. The hostess is then a key person of the phenomenon. She supports the debaters in turn and therefore provokes the polemic. She does not let enough space and time to develop an opinion, and does not provide any synthesis. Eventually, she apparently delegates her chairing identity to the participants coming from the audience.

These properties are typical of what we call the "statement's talk show debate", which is a genre actually in vogue in the broadcast media. The "statement's talk show debate" seems to reveal a change of the role of the media in participating to the construction of public opinion. A "civic debate" aims at informing critically about the ongoing of the public sphere. All participants as well as the audience are considered as citizens. In this sense, the media play the role of a "mediator" between the public sphere of citizens and the private sphere of individuals. The "chat talk show debate" exploits the same fundamental dimensions of every debate: it makes explicit a public state of affairs and discusses it by means of the confrontation of opinions. Nevertheless, this latter dimension is dominant and this is why a "chat talk show debate" becomes easily an entertaining show hosted by a 
popular media employee. The "statement's talk show" definitely mixes up the frames: the public sphere (i.e. all issues that are of interest to all citizens) is clearly viewed by participants talking and acting as individuals and not as group members and citizens. In this sense, private states of affairs become legitimate public issues ${ }^{7}$. On the one hand, what is at stake with "statement's talk show debates" is the exploiting of media information in order to win customers loyalty. On the other hand, the practice of media debates, especially those that are based on audience participation, has as a consequence to question what democracy is or should be. Then, the role of discourse in constituting the social practices of the media seems essential: neither opinions nor stories can be expressed without discourse; there is no alternative but discourse to meta-communicate; a negotiation implies a discursive anchorage; only discourse constitutes a comprehensive means to share social representations etc. Eventually, discourse supports the construction of human identities and societies. In this respect, the discourse of the media constitutes a revelator that is paradoxically still minimized in the field of communication and media studies. This paper calls for the relevance of a discourse analytical approach taking into account the verbal units performed by the participants engaged in particular social practices. Indeed, in the broadcast we are concerned with, the discursive performance of the hostess is crucial. Discourse is the means to anchor the event in the particular category of "statement's talk show": shortening the phase 1 and avoiding the phase 3 of the debates sequences contributes to favor potentially entertaining polemics; requesting the expression of "private" experiences by individuals contributes to focus the debate on self-centered topics and talks; encouraging and exploiting confrontation without argumentation leads to increase the part of emotion and affect etc. In other words, the kind of discursive actions locally but systematically performed by the hostess contribute to construct the frame of a "statement's talk show", which implies to blur the boundaries between the private and the public spheres. Thus, our claim is that a close attention paid to local discursive actions reveals such strategies and what is at stake with it in terms of media culture much better than a global content analysis.

\section{Notes.}

1. I use the general term of "Media debates" to refer to a broadcast media event dominated by verbal confrontation, including the "confrontainment" dimension (i.e. a mix between "argumentative" confrontation aimed at convincing and confrontation as pure entertainment aimed at contributing to a show) manifested by talk shows. The general category of "Media debates" will be detailed in section 3.3 .

2. For the distinction between a "talk with" and a "talk for" relation, see Jucker (1995). See Isotalus (1998) for more relevant details about the communicative dimension of the media.

3. The paradoxical constraints on the activity of media information are discussed in Livingstone and Lunt (1994), Bourdieu (1996), Charaudeau (1997).

4. There are numerous papers dealing with the issue of debates. Charaudeau (ed.)(1991), Nel (1991), Charaudeau and Ghiglione (1997), Livingstone and Lunt (1994), Shattuc (1997), Hutchby 
(1999), Tolson (ed.) (2001) are relevant references.

5. Of course, this latter issue is polemic. On the one hand are arguments in favor of "statement's talk-show debate" as a manifestation of a new democracy realized by lay participation. On the other hand, are arguments in favor of the essential role of expertise and a pedagogical hosting of debates (for a discussion see: Livingstone and Lunt, 1994; Shattuc, 1997; Bourdieu, 1996).

6. For a discussion of the issue of identity and the displaying of identities in discourse see: Shotter and Gergen (eds)(1989), Zimmerman (1998), Burger (2002a); for the construction of identities in media discourse see: Burger (2002b; 2004; 2005), Burger and Filliettaz (2002). In general, one has to make a difference between a "communicative status" and a "role identity". The former manifests an identity relevant during the whole communicative event: being a host, a debater, a television viewer etc. The latter manifests a more "local" identity expected by a "status", that is doing something recurrently like: limiting the floor, provoking a confrontation, stirring up the confrontation, exploiting the reactions of the audience etc.

7. This seems to be the case in other European media cultures: Germany, The Netherlands, U.K., Italy, Spain, and Portugal at least.

\section{References}

Bell, Allan and Peter Garrett (1998): Approaches to Media Discourse. Oxford: Blackwell. Bourdieu, Pierre (1996): Sur la télévision. Suivi de L'emprise du journalisme. Paris: Ed. Raisons d'Agir.

Bronckart, Jean-Paul (1997): Activité langagière, textes et discours. Paris : Delachaux et Niestlé. Burger, Marcel (2002a): Les manifestes: paroles de combat. De Marx à Breton. Paris: Delachaux et Niestlé.

. (2002b): "Identities at Stake in Social Interaction: the case of Media Interviews". Studies in Communication Sciences 2/2: 1-20.

. (2002c): "Encenaçõ discursivas na mídia : o caso do debate-espetáculo". In I. Machado, H. Mari and R. De Mello, eds., Ensaios em Análise do Discurso. Belo Horizonte: NAD/FALE/UFMG, 201-222.

. (2004): "The Function of the Discourse of the Host in a TV Talk Show". In C. A.M. Gouveia, M. Carminda Silvestre and Luísa Azuaga, eds., Discourse, Communication and the Enterprise: Linguistic Perspectives. Lisbon: Ulices, 345-358.

. (2005): "La complexité argumentative d'une séquence de débat politique médiatique". In M. Burger and G. Martel, eds., Argumentation et communication dans les médias. Québec: Nota Bene, 51-79.

. (in press): "La construction conjointe des rôles interactionnels dans l'entretien médiatique télévisé de personnalités". In D. Vincent, ed., Interactions asymétriques. Communications privées, institutionnelles et médiatiques. Québec: Nota Bene.

. (ed.)(forthcoming): L'analyse linguistique des discours des médias : théories, méthodes et perspectives. Québec: Nota bene.

Burger, Marcel and Guylaine Martel (eds.) (2005): Argumentation et communication dans les médias. Québec: Nota Bene.

Burger, Marcel and Laurent Filliettaz (2002): "Media interviews: An intersection of multiple 
social practices". In Ch. N. Candlin, ed., Research and Practice in Professional Discourse. Hongkong: City University Press, 567-588.

Charaudeau, Patrick (ed.)(1991): La télévision. Les débats culturels 'Apostrophes'. Paris: Didier Erudition.

. (1997): Le discours d'information médiatique. Paris: Nathan.

(2005): Le discours politique. Les masques du pouvoir. Paris: Vibert.

Charaudeau, Patrick and Rodolphe Ghiglione (1997): La parole confisquée. Paris: Dunod.

Cicourel, Aaron (1991): "Semantics, pragmatics, and situated meaning". In J. Verschueren, ed.,

Pragmatics at Issue, vol 1. Amsterdam: John Benjamins, 37-66.

Croteau, David and William Hoynes (2001): The Business of Media. Corporate Media and the

Public Interest. London: Pine Forge Press.

Dijk Van, Teun A. (1990): "Social cognition and discourse". In H. Giles and P. W. Robinson, eds., Handbook of language and social psychology. Chichester: Wiley and Sons, 163-186.

(1991): Racism and the Press. London: Routledge.

(1997): "Discourse as Interaction in Society". In T. A.Van Dijk, ed., Discourse as

Social Interaction. London: Sage, 1-37.

Fairclough, Norman (1995): Discourse and Social Change. Cambridge: Polity Press.

Filliettaz, Laurent (2002): La Parole en action. Eléments de pragmatique psychosociale. Québec:

Nota Bene.

Goffman, Erving (1973): La mise en scène de la vie quotidienne, t. 1, Paris, Minuit.

(1983): "The interaction order". American Sociological Rewiev 48: 1-17.

Haarman, Louhann (2001): "The perfoming talk". In A. Tolson, ed., Television Talk Shows.

London: Lawrence Erlbaum Associates, 31-64.

Habermas, Jürgen (1987): La théorie de l'agir communicationnel. Paris: A. Fayard.

. (1993): “Actions, actes de parole, interactions médiatisées par le langage et monde vécu". In La pensée postmétaphysique. Essais philosophiques. Paris: Colin, 67-104.

Harre, Rom and Grant Gillett (1994): The Discursive Mind. London : Sage.

Hutchby, Ian (1999): "Rhetorical Strategies in Audience Participation Debates on Radio and TV". Research on Language and Social Interaction 32(3): 243-267.

. (2001): "Confrontation as a spectacle: The argumentative frame of the Ricki Lake Show". In A. Tolson, ed., Television Talk Shows. London: Lawrence Erlbaum Associates, 173-192.

Isotalus, Pekkla (1998): "Television performance as interaction". Nordicom Review 19/1: 175-183.

Jacobs, Geert (1999): Preformulating the News. Amsterdam: Benjamins Publishing Company. Jost, François (2001): La Télévision du quotidien. Entre réalité et fiction. Bruxelles: De Boeck. Jucker, Andreas H. (1995): "Mass Media". In J. Verschueren, J. O. Ostman and J. Blommaert, eds., Handbook of Pragmatics. Amsterdam: Benjamins, 1-14.

Levinson, Stephen(1992): "Activity Types and Language”. In P. Drew and J. Heritage, eds., Talk at Work. Cambridge: Cambridge University Press, 66-100.

Livingstone, Sonia and Peter Lunt (1994): Talk on Television. Audience Participation and Public Debates. London: Routledge.

Lochard, Guy and Jean-Claude Soulages (1993): “Talk-Show: la part de l'image”. Psychologie française $38(2)$ : 145-160.

Maigret Eric and Eric Macé (2005) : Penser les médiacultures. Nouvelles pratiques et nouvelles 
approches de la représentation du monde. Paris: Colin.

Myers, Greg (2001): "I'm out of it; You guys argue: Making an issue of it on the Jerry Springer Show". In A. Tolson, ed., Television Talk Shows. London: Lawrence Erlbaum Associates, 173-192.

Nel, Noël (1991): Le débat télévisé. Paris: Colin.

Neveu Erik (2001): Une société de communication? Paris : Montchrestien.

Perrin, Daniel (2006): Medienlinguistik. Konstanz : UVK Verlagsgesellschaft mbH.

Perrin, Daniel and Maureen Ehrensberger (forthcoming): "Progression Analysis: Tracing Journalistic Language Awareness". In M. Burger, ed., L'analyse linguistique des discours des médias : théories, méthodes et perspectives. Québec: Nota bene.

Scannell, Paddy (1991): "Introduction : the Relevance of Talk". In Broadcast Talk. London: Sage, $1-13$.

Scollon, Ron (1998): Mediated Discourse as Social Interaction. A Study of News Discourse. London: Longman.

Shattuc, Jane (1997): The Talking Cure. London: Routledge.

Shotter, John (1995): Conversational Realities. London: Sage.

Shotter, John and Kenneth Gergen (eds)(1989): Texts of Identity. London: Sage.

Siracusa, Jacques (2002): Le JT Talking Cure. Paris: De Boeck.

Tolson, Andrew (2001): "Introduction: the talk show phenomenon" and "Talking about talk: The academic debates". In A. Tolson, ed., Television Talk Shows. London, Lawrence Erlbaum Associates, 1-6, 7-30.

Trognon, Alain and Janine Larrue (1994): "Les débats politiques télévisés". In Pragmatique du discours politique. Paris: Colin, 55-126.

Zimmerman, Don H. (1998): "Identity, context and interaction". In Ch. Antaki and S. Widdicombe, eds., Identities in Talk. London: Sage, 87-106.

\section{Appendix 1}

The following minimal transcription conventions are used:

(Pauses):

Underlining:

[Square brackets]:

Number in margin: "Quotationmarks":
(.), (..), (...) indicate appropriately timed pauses; indicates overlapping talk; material in square brackets indicates transcriber's commentary regarding non-verbal events;

the numbers in the left margin indicate each line of the transcribed text; information like "host" or "debater" refer to the current speaker's identity. The information on the right of the text, like "stage 1 " refer to the structural properties of a debate sequence as detailed in section 4.3. 